\title{
Habitat Suitability Modeling of Bornean Orangutan (Pongo pygmaeus pygmaeus) in Betung Kerihun National Park, Danau Sentarum and Corridor, West Kalimantan
}

\author{
Hari Prayogo ${ }^{1 *}$ Achmad Machmud Thohari', Dedy Duryadi Solihin ${ }^{3}$, \\ Lilik Budi Prasetyo ${ }^{2}$, Jito Sugardjito $^{4}$
}

\begin{abstract}
${ }^{1}$ Graduate School of Bogor Agricultural University, Dramaga Main Road Campus IPB Dramaga, Bogor, Indonesia 16680 ${ }^{2}$ Department of Forest Resources Conservation and Eco-tourism, Faculty of Forestry IPB, Bogor Agricultural University, Academic Ring Road, Campus IPB Dramaga, PO Box 168, Bogor, Indonesia 16680

${ }^{3}$ Department of Biology, Faculty of Mathematic and Natural Sciences, Bogor Agricultural University, Academic Ring Road, Campus IPB Dramaga, Bogor, Indonesia 16680

${ }^{4}$ Faculty of Biology, Universitas NasionalJl. Sawo Manila, Pejaten, Pasar Minggu, Jakarta, Indonesia 12520
\end{abstract}

Received June 18, 2014/Accepted August 25, 2014

\begin{abstract}
Conservation areas such as national parks became the last safe area for biodiversity in Indonesia, especially for orangutan, because they have permanent status, and other forest areas may change at any time. Currently, there have been tremendous numbers of land use changes in orangutan habitats such as the development of roads, large scale plantations, settlements, farming as well as logging. However, the available national parks still offer secure places for orangutans. This research was conducted to study the impact of spatial land use policy on the habitat distribution of orangutans. A remote sensing technology was used to study the habitat distribution and suitability of orangutan in Betung Kerihun National Park (BKNP), Danau Sentarum National Park (DSNP) and a corridor which connects these 2 parks. Seven parameters have been observed to characterize the habitat of orangutans. Habitat suitability levels of three research sites i.e. BKNP, corridor, and DSNP were $53.72 \%, 42.94 \%$, and $3.34 \%$ which is considered as high, moderate, and low level of habitat suitability, respectively. These results were obtained with $93.63 \%$ of validation.
\end{abstract}

Keywords: orangutan, habitat suitability, remote sensing technology, validation

*Correspondence author; email: hpyogo@yahoo.com,tel.:+62-85654479000

\section{Introduction}

Kapuas Hulu is a conservation district in West Kalimantan, based on Kapuas Hulu Regent Decree Number 144/2003. This district has 2 national parks namely Betung Kerihun and Danau Sentarum. These parks are of importance as last habitat of bornean orangutan (Pongo pygmaeus) in Borneo, and the government of Kapuas Hulu has identified a corridor, a region to connect the 2 national parks. This area has also been designated as a strategic area district (kawasan strategis kabupaten) which is very important in terms of environmental concerns. One of the important fauna that exists in this region and national park is the bornean orangutan (Pongo pygmaeus), which also has become a global conservation icon (Wich et al. 2012a).

Orangutans (Pongo spp.) are the only great ape liveing in South East Asia and are found in the islands of Sumatra and Borneo (Warren et al. 2001; Nijman \& Meijaard 2008; Gossens et al. 2008; Locke et al. 2011). According to Rijksen \& Meijaard (1999), Singleton et al. (2004), and Wich et al. (2008), the population of orangutan has significantly decreased which makes orangutans endangered species.
Moreover, in 2000, IUCN listed bornean orangutan as endangered, while Sumatran orangutan was classified as critically endangered (Ancrenaz et al. 2008; IUCN 2014). In the past, orangutan was considered to be a single species, namely P. pygmaeus. Recently, however, the previous author, has differentiated it into 2 subspecies namely $P$. p. pygmaeus for bornean orangutan and $P$. p p abelii for sumatran orangutan (Muir et al. 2000). Nowadays, after the genetic study has confirmed with morphological analysis, the bornean orangutan has been divided into 3 sub-species namely P.p.pygmaeus, P. p. wurmbii, and P. p morio (Groves 2001; Warren et al. 2001).

Research in biological conservation has widely made use of remote sensing technology (Allouche et al. 2008). One of the advantages is its ability to determine the habitat of orangutan comprehensively. Prediction on extent and characteristics of a particular area can be conducted relatively easily, efficient, cheap, and faster than through direct measurements in the field.

Area management becomes less effective if it is not supported by comprehensive data of habitat and distribution of endangered species. Geographic information systems 
(GIS) combined with multivariate analysis have been used to determine habitat suitability, and it could support the development of maps on the potential distribution of endangered species such as orangutan (Guisan \& Zimmermann 2000; Hirzel et al. 2004; Chefaoui et al. 2005). Several authors have used the remote sensing technology approach for their studies. Long et al. (2008) has used Landsat technology to measure the population and status of endangered shorebirds in Madagascar. Engler et al. (2004) have used spatial model to measure habitat suitability of conserved species. Ikbal et al. (2008) have used this technology to measure the habitat suitability of javan gibbon, while Rahmat et al. (2012) used it for javan rhino. Wich et al. (2012b) have developed a model for the conservation plan of orangutan in Borneo.

GIS technology could provide the latest data sources such as land cover, vegetation, and other habitat which combined with data generated from satellite image such as elevation, water surface, climate data and land types can be used for wild animal and area conservation mana-gement purposes (Larson et al. 2003). Satellite technology has been used to study the distribution of orangutan in this area through assessing condition and spatial distribution and habitat quality. The objectives of this research are to study the spatial distribution and habitat suitability of orangutan ( $P . p$. pygmaeus) in Betung Kerihun National Park (BKNP), Danau Sentarum National Park (DSNP), and the corridor that links these national parks.

\section{Methods}

The study area comprised BKNP, DSNP, and the forest area which links those 2 national parks. The whole area of this research is situated at the north side of Kapuas River, Kapuas Hulu District, West Kalimantan (Figure 1). This research was conducted from March 2011 to December 2012.

Data of orangutan distribution were collected based on the existence of orangutan nests. Nests were determined through purposive sampling method based on the information of community and staff of national parks. Nests are relatively easy to find since orangutans make nests every day (Wich et al. 2012a). The research site was determined by considering the condition of location that can represent the area of the research site. Coordinates of nest and signs representing the presence of orangutan (trail) was marked and recorded using global position system (GPS). The land cover condition, road, river, and village near the research site were also recorded.

Mapping of orangutan distribution Habitat suitability data was collected from primary and secondary data. Primary data referred to the positions of orangutans, their trail, and nest. Secondary data was obtained from literature, digital map, and respondent. Other parameters were the position of

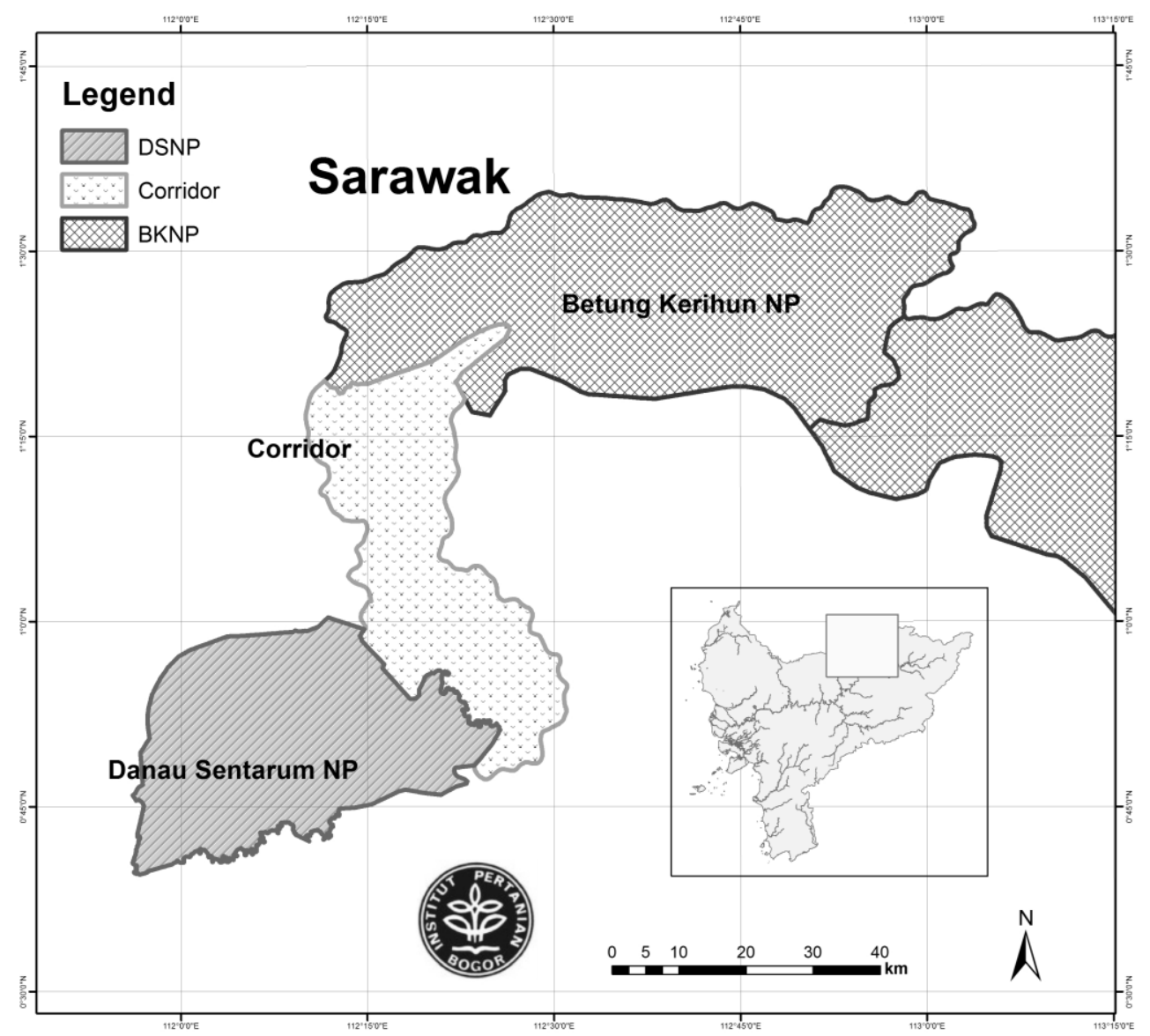

Figure 1 Research location in Betung Karihun National Park (BKNP), Danau Sentarum National Park (DSNP), and corridor area. 
villages near the research site, roads, rivers, and land condition inside and near the area of the research site. Data was classified by its function, e.g. data of coordinate points from GPS, location of trails/nests of orangutans, forestry thematic base map from Forestry Planning Agency, boundary delineation map of DSNP and BKNP, shuttle radar topography mission (SRTM) map, and Landsat Image 8ETM path 120 row 059 and path 119 row 059 were used to develop maps of orangutan distribution and habitat suitability. Data processing was performed using Microsoft Excel 2003, Minitab 16, ArcGIS version 9.3, and Erdas Imagine 9.1 software.

Parameters used to develop habitat suitability were (1) distance from settlement, (2) distance from road, (3) distance from large river, (4) distance from small river, (5) slope, (6) altitude, and (7) land cover which was generated from normalization difference vegetation index (NDVI). Weighing was calculated from the result of the research and based on the above parameters. In ecology to seven parameters gives a significant impact on orangutans. Settlements, roads, and large rivers are related to human activity, or the level of human disturbance on orangutans, 4 other parameters associated with the preferred habitat of orangutans, for example the availability of vegetation as a source of food and ease of moving.

Map development NDVI NDVI map was used to estimate the vegetation density which is obtained from measuring and mapping green color vegetation. NDVI value was measured through image processing by selecting band (light wave) of red (R) and infra-red (IR). Landsat image was then analyzed using Erdas imagine 9.1 software. NDVI calculations performed on the model maker ERDAS according to the Equation [1]:

$$
\mathrm{NDVI}=\frac{(\mathrm{IR}-\mathrm{R})}{(\mathrm{IR}+\mathrm{R})}
$$

NDVI values were taken as orangutans depend on the vegetation in the habitat, from daily activities was known that orangutans are always moving to find food resources in the form of fruits.

Principal component analysis (PCA) PCA was used to determine the most significant factors that contribute to the distribution of borneon orangutan based on the distribution point found at each layer. As much as $70 \%$ of the total points were used to develop a model, while the remaining 30\% were used to validate the model. According to the result, weight of each factor that influenced, the habitat distribution of borneo orangutan could be determined. Analysis was carried out using Minitab 16 software. The result from PCA which used to determine the weight of each factor and spatial analysis was formulated as shown in Equation [2].

$\mathrm{Y}=\mathrm{aFk} 1+\mathrm{bFk} 2+\mathrm{cFk} 3+\mathrm{dFk} 4+\mathrm{eFk} 5+\mathrm{fFk} 5+\mathrm{gFk} 7$

note: $\mathrm{Y}=$ total value of habitat suitability

a-f $=$ weight value of each variable

$\mathrm{Fk} 1=$ distance from large river

$\mathrm{Fk} 2=$ distance from small river

$\mathrm{Fk} 3=$ distance from road

$$
\begin{aligned}
\text { Fk4 } & =\text { distance from settlement } \\
\text { Fk5 } & =\text { NDVI } \\
\text { Fk6 } & =\text { slope } \\
\text { Fk7 } & =\text { altitude/topography }
\end{aligned}
$$

Spatial analysis Several factors used for spatial analysis were distribution points of orangutans measured as distance from rivers, roads, and villages and also NDVI value. The analysis methods were overlaying, classifying, weighing, and scoring. Weighing was based on the importance or habitat suitability of borneo orangutan. and comprised of three levels of value. The highest value indicated the most impact habitat factor (IKH3), lower value indicated moderate impact habitat factor (IKH2), and the lowest indicated less impact habitat factor (IKH1).

\section{Results and Discussion}

Orangutans are a predominantly arboreal primates, which will choose the most suitable habitat to satisfy their needs. The selection of this habitat is a process. The behavior of orangutans enabling the habitat selection process assures the proliferation and survival and as well provides a sense of security and comfort (Majka et al. 2007). A total of 802 points in the form of nests and traces of orangutans were found in BKNP, DSNP, and corridors.

Habitat suitability of orangutan in relation to distance from settlement Settlements influenced the habitat of orangutan significantly. They were only found in the corridor, DSNP area and were generally dominated by Dayak ethnic group in the former and Malay the latter.

Table 1 shows that trail/nest of orangutan was rarely found within 0-3,000 $\mathrm{m}$ distance from settlements. Local people were used to hunt in the area closes to their houses. When they hunted pig and deer, they probably also caught orangutans. Many trails or nests of orangutans were found at distances of more than 3,000 $\mathrm{m}$ which indicated that this area was relatively safe. Soemarna et al. (1995) stated that orangutans are very sensitive to hunting. According to the map of hunter communities and s of indigenous people, it became apparent that a place without orangutan population was likely the center of a hunting tribe (Bugo 1995). At a distance of $>7,000 \mathrm{~m}$ density is low because the area covered is very wide and the other parameters take effect, as slope and elevation. In addition, the area around the settlement was mostly under cultivation area therefore not suitable as a habitat for orangutans.

Habitat suitability of orangutan in relation to distance from road Roads were the other factor which heavily impacted the habitat suitability of orangutans due to their function for transportation and provision of access for animal hunting. Road network development also plays a role in fragmenting animal home ranges including that of orangutans.

As transportation infrastructure, the environmental impact from road could also be in the form of noise. In addition, the road development attracts people to develop settlements and open farming areas along side roads. Therefore, trails/nests of orangutans were rarely found 
within a distance of $0-3,000 \mathrm{~m}$ from the road. There were only 32 nest (the density was $0.068 \mathrm{ha}^{-1}$ and $0.143 \mathrm{ha}^{-1}$ ). The distance of more than $3,000 \mathrm{~m}$ from road was safer for orangutans, with a density of more than $0.9 \mathrm{ha}^{-1}$ (Table 2). During time of intense illegal logging, the research site at the forest area around the road was also one of the logging areas. This condition caused serious habitat change, including area size, quality and pathway patterns forcing orangutans away from logging areas in order to maintain their viability (Meijaard et al 2001). At the time of rampant illegal logging, the area around the road into the target area of illegal logging, the forest is being damaged as a result, so it is not suitable as a habitat for orangutans.

Habitat suitability of orangutan in relation to distance from large river Many rivers occur in the research site. Large rivers include Embaloh, Leboyan, and Kapuas. The upper course of Embaloh River lies within BKNP which then flows into Kapuas River. The upper course of Leboyan lies within BKNP as well and then flows through corridor and into DSNP.

Table 3 shows that few orangutans ( 28 nests) prefer areas close to the large river within a distance $0-5,000 \mathrm{~m}$. Density at the closest area was $0.03 \mathrm{ha}^{-1}, 0.082 \mathrm{ha}^{-1}$, and $0.006 \mathrm{ha}^{-1}$. Distribution of orangutans at longer distance was higher than $90 \%$ with a density of $0.19 \mathrm{ha}^{-1}$ and $0.176 \mathrm{ha}^{-1}$, respectively. This indicates that orangutan did not feel safe at close to large rivers. Many motorized boats pass produce noise which can cause discomfort for orangutans. In
Sumatra and Boreo, large number of orangutan occur near small rivers and swamp areas, the highest density was found at small forest area (alluvial) in river valley and tidal forest area near the swamp area or among rivers (Meijaard et al. 2001). Similarly to the situation with roads, the great river are also regions of land clearing for plantations and illegal logging, being unsuitable as a habitat for orangutans.

Habitat suitability of orangutan in relation to distance from small rivers Kalimantan is commonly known as island with thousand rivers. Most of the nests were found in distance class $0-4,000 \mathrm{~m}(90.78 \%)$ from small rivers (Table 4). Small rivers are generally surrounded by interconnected canopy vegetation that allow orangutans to move easily. Small rivers are not too deep and may contain rocks which makes crossing of rivers easier (Meijaard et al 2001).

A high diversity of fruit plants could increase the possibility of discontinuous seasonal peaks in the availability of fruits. This condition is found in alluvial area including swamp area (Leighton \& Leighton 1983; van Schaik et al. 1995) or wide valley rivers (Meijaard et al. 2001). However, the frequency of fruits production depends on the soil fertility and water availability.

Habitat suitability of orangutan in relation to slope Highest numbers of orangutans nest were commonly found at slopes of less than $40 \%$. A total of 273 nests were found at

Table 1 Distribution of nest and area by distance from settlement

\begin{tabular}{ccrcrc}
\hline Class $(\mathrm{m})$ & Number of nest & $\%$ & Area (wide) & \multicolumn{1}{c}{$\%$} & Nest density ha $^{-1}$ \\
\hline $0-1,000$ & 4 & 0.50 & $11,852.93$ & 2.33 & 0.034 \\
$1,000-3,000$ & 84 & 10.47 & $47,187.74$ & 9.26 & 0.178 \\
$3,000-5,000$ & 378 & 47.13 & $53,706.54$ & 10.54 & 0.704 \\
$5,000-7,000$ & 246 & 30.67 & $46,637.54$ & 9.15 & 0.527 \\
$>7,000$ & 90 & 11.22 & $350,171.89$ & 68.72 & 0.026 \\
\hline Total & 802 & 100 & $509,556.64$ & 100 & \\
\hline
\end{tabular}

Table 2 Distribution of nest and area by distance from road

\begin{tabular}{cccccc}
\hline Class $(\mathrm{m})$ & Number of nest & $\%$ & Area (wide) & $\%$ & Nest density ha $^{-1}$ \\
\hline $0-1,000$ & 8 & 1.00 & $11,728.39$ & 2.30 & 0.068 \\
$1,000-3,000$ & 24 & 2.99 & $16,813.68$ & 3.30 & 0.143 \\
$3,000-5,000$ & 176 & 21.95 & $17,995.10$ & 3.53 & 0.978 \\
$5,000-7,000$ & 213 & 26.56 & $22,918.68$ & 4.50 & 0.929 \\
$>7,000$ & 381 & 47.51 & $440,100.79$ & 86.37 & 0.087 \\
\hline Total & 802 & 100 & $509,556.64$ & 100 & \\
\hline
\end{tabular}

Table 3 Distribution of nest and area by distance from large river

\begin{tabular}{cccccc}
\hline Class $(\mathrm{m})$ & Number of nest & $\%$ & Area (wide) & $\%$ & Nest density ha $^{-1}$ \\
\hline $0-1,000$ & 4 & 0.50 & $13,502.70$ & 2.65 & 0.030 \\
$1,000-3,000$ & 22 & 2.74 & $26,803.28$ & 5.26 & 0.082 \\
$3,000-5,000$ & 2 & 0.25 & $32,076.94$ & 6.30 & 0.006 \\
$5,000-7,000$ & 61 & 7.61 & $32,114.86$ & 6.30 & 0.190 \\
$>7,000$ & 713 & 88.90 & $405,058.87$ & 79.49 & 0.176 \\
\hline Total & 802 & 100 & $509,556.64$ & 100 & \\
\hline
\end{tabular}


0-8\% slope with density of $0.148 \mathrm{ha}^{-1}$. At steeper slopes, orangutans require more energy for their daily activities. Therefore, they prefer areas with lower slope (Table 5). Density of orangutans in upland area was found to be less than 1 ind $\mathrm{km}^{-2}$. This condition also occurs at open forest or highly damaged forest area (Rijksen \& Meijaard 1999; Ancrenaz et al. 2008). In Kalimantan, orangutan was distributed throughout the island except at mountainous and low land area with dense human population (Rijksen \& Meijaard 1999). For hill area with slope higher than 40\%, it could only be found 24 nests with density of $0.025 \mathrm{ha}^{-1}$.

Habitat suitability of orangutan in relation to elevation Nests of orangutans could only be found at altitude of between 0-500 m. Orangutans preferred areas at altitude of $0-300 \mathrm{~m}$ in which 746 nests or $93.02 \%$ of the total nests with density of $0.300 \mathrm{ha}^{-1}$ were found (Table 6). This finding confirmed previous results which stated that orangutans in are distributed at altitude lower than $500 \mathrm{~m}$ asl (Sugardjito \& van Schaik 1991; Groves 2001). Moreover, Payne (1987), and van Schaik et al. (1991) stated that orangutan preferred to live at lowland areas where the highest density occurred at altitude of $200-400 \mathrm{~m}$.

Habitat suitability of orangutan in relation to NDVI Vegetation index describes the greenness level of plants which is mathematically generated from the combination of red band and near infra red (NIR) band that has long been used as an indicator of the presence and condition of vegetation (Lillesand \& Kiefer 1997). Landsat image 8TM on June 27 and July 42013 showed that BKNP area still had very good land cover as the location is difficult to be accessed by people. An open area was shown at the location around corridor and DSNP area. At the corridor area, almost all people converted forest area into farming area. The area far from the river was dominated by old secondary forest or primary forest.

Table 7 shows that NDVI is quite varied. Values of less than 0 indicate bodies of water. The highest nest distribution occurred in the $0.3-0.4$ and $0.4-0.5$ class with densities of $0.121 \mathrm{ha}^{-1}$ nest and $0.32 \mathrm{ha}^{-1}$, respectively. The area of this class was young secondary forest, secondary forest, old secondary forest, and primary forest. Values higher than 0.5 indicated secondary forest and part of it was plantation area.

Table 4 Distribution of nest and area by distance from small river

\begin{tabular}{rcrrrc}
\hline Class $(\mathrm{m})$ & Number of nest & $\%$ & Area (wide) & \multicolumn{1}{c}{$\%$} & Nest density ha $^{-1}$ \\
\hline $0-2000$ & 240 & 29.93 & $294,195.15$ & 57.74 & 0.082 \\
$2000-4000$ & 488 & 60.85 & $119,048.39$ & 23.36 & 0.410 \\
$4000-6000$ & 73 & 9.10 & $54,058.06$ & 10.61 & 0.135 \\
$6000-8000$ & 1 & 0.12 & $17,557.04$ & 3.45 & 0.006 \\
$>8000$ & 0 & 0.00 & $24,698.01$ & 4.85 & 0.000 \\
\hline Total & 802 & 100 & $509,556.64$ & 100 & \\
\hline
\end{tabular}

Table 5 Distribution of nest and area by slope

\begin{tabular}{ccccrc}
\hline Class (\%) & Number of nest & $\%$ & Area (wide) & \multicolumn{1}{c}{$\%$} & Nest density ha $^{-1}$ \\
\hline $0-8$ & 273 & 34.04 & $184,634.02$ & 36.23 & 0.148 \\
$8-15$ & 132 & 16.46 & $33,903.90$ & 6.65 & 0.389 \\
$15-25$ & 144 & 17.96 & $65,375.42$ & 12.83 & 0.220 \\
$25-40$ & 229 & 28.55 & $129,368.26$ & 25.39 & 0.177 \\
$>40$ & 24 & 2.99 & $96,275.04$ & 18.89 & 0.025 \\
\hline Total & 802 & 100 & $509,556.64$ & 100 & \\
\hline
\end{tabular}

Table 6 Distribution of nest and area by height

\begin{tabular}{cccccc}
\hline Class (m asl) & Number of nest & $\%$ & Area (wide) & $\%$ & Nest density ha $^{-1}$ \\
\hline $0-300$ & 746 & 93.02 & $248,338.42$ & 48.74 & 0.300 \\
$300-400$ & 46 & 5.74 & $74,161.13$ & 14.55 & 0.062 \\
$400-500$ & 10 & 1.25 & $72,177.66$ & 14.16 & 0.014 \\
$500-750$ & 0 & 0.00 & $87,945.10$ & 17.26 & 0 \\
$>750$ & 0 & 0.00 & $26,934.33$ & 5.29 & 0 \\
\hline Total & 802 & 100 & $509,556.64$ & 100 & \\
\hline
\end{tabular}


The value was high due to more intensive photosynthesis compared to secondary and primary forest.

Data analysis of habitat suitability model The model was developed through PCA. Three principal components and their total diversity which was obtained from the analysis of 7 principal components (Table 8). The principal component that could be used was the third with a total diversity value of $76.1 \%$. The cumulative diversity value is assumed to represent the total diversity as the cumulative diversity ranges from $70 \%-80 \%$ (Timm 2002 ).

The analysis result (total value of trait root) was then used to determine the weight of each variable. The correlation among 7 habitat suitability variables of orangutan with principal component is shown in Table 8. Weight of each variable to determine the model of habitat suitability of orangutan was obtained from PCA trait vector of each variable that had the highest positive value against the resulted principal component. The above result shows that variables of small rivers, height, and slope had high positive correlation against the first principal component. Meanwhile, variable of settlement and road had high positive correlation against the second principal component. Variable of large river and NDVI had high positive correlation against the third principal component. Weight of each variable is shown in Table 9.

Based on the calculation using Minitab 16 of each variable, the equation of habitat suitability model of orangutan in BKNP, corridor, and DSNP is shown in Equation [3]

Table 8 Total diversity of principal component

\begin{tabular}{|c|c|c|c|c|}
\hline \multirow{2}{*}{ Component } & \multicolumn{4}{|c|}{ Root of traits } \\
\hline & Total & Diversity (\%) & Diversity & cumulative $(\%)$ \\
\hline 1 & 2.4354 & 34,8 & & 34,8 \\
\hline 2 & 1.5753 & 22,5 & & 57,3 \\
\hline 3 & 1.3144 & 18,8 & & 76,1 \\
\hline
\end{tabular}

Table 9 Coefficient of each habitat suitability variable of orangutan (P. p. pygmaeus)

\begin{tabular}{lc}
\hline Variable & Weight \\
\hline Large river (LR) & 1.3144 \\
Settlement (Set) & 1.5753 \\
Small river (SR) & 2.4354 \\
Road (Rd) & 1.5753 \\
Altitude (Alt) & 2.4354 \\
Slope (elev) & 2.4354 \\
NDVI & 1.3144 \\
\hline
\end{tabular}

Table 10 Habitat suitability index value of orangutan in BKNP, corridor, and DSNP

\begin{tabular}{|c|c|c|c|c|}
\hline Range & Category & Wide (ha) & Proportion (\%) & Suitability classification \\
\hline $24.5284-38.1616$ & IKH1 & $7,023.264$ & 3.341 & Low \\
\hline $38.1616-51.7948$ & $\mathrm{IKH} 2$ & $218,804.856$ & 42.942 & Moderate \\
\hline $51.7948-65.428$ & IKH3 & $273,708.372$ & 53.717 & High \\
\hline Total & & $509,536.493$ & 100 & \\
\hline
\end{tabular}


karst as peat swamp forest consistently provides feed resources such as fruits for orangutan (Cannon et al. 2007).

Areas with low habitat suitability i.e. $3.34 \%$ or equal is comprising 7,023.26 (Figure 2) and are close to the settlements area in the corridor and such higher than $750 \mathrm{~m}$ asl. Borneo orangutans preferred habitat with altitude lower than $500 \mathrm{~m}$.

Validation The validation phase is crucial in assessing the accuracy of predictions. This is achieved by testing the potential distribution of a species represented by the habitat suitability model against evidence recorded in the field (Ottaviani et al. 2004). Validation was performed to test the developed model using 267 location points obtained around $30 \%$ from all observation data. Validation was conducted using a map of habitat suitability model and validation points which were then overlaid. The validation value was obtained by using the difference between the highest and lowest values and the results are divided into 3 proportions that represent low, medium, and high. If moderate and high suitability level were combined together, it equals to $93.63 \%$ (moderate $=$ $65.92 \%$ and high $=27.76 \%$ ) which indicated that research site was suitable as habitat of orangutans (Table 11).

As appropriate locations as habitat for orangutans, rank both high or medium in BKNP, DSNP or corridor these should be maintained in their present state. In addition, a network of small rivers which have high suitability can serve as a wildlife corridor that connects the entire area, so as to accommodate the movement of orangutans from the 3 study sites.

\section{Conclusion}

Habitats of $P$. p. pygmaeus in Kalimantan are still left in BKNP, corridor, and DSNP. These areas are important for the conservation of this species. The most suitable habitat for orangutans indicated by the number of nests or traces are

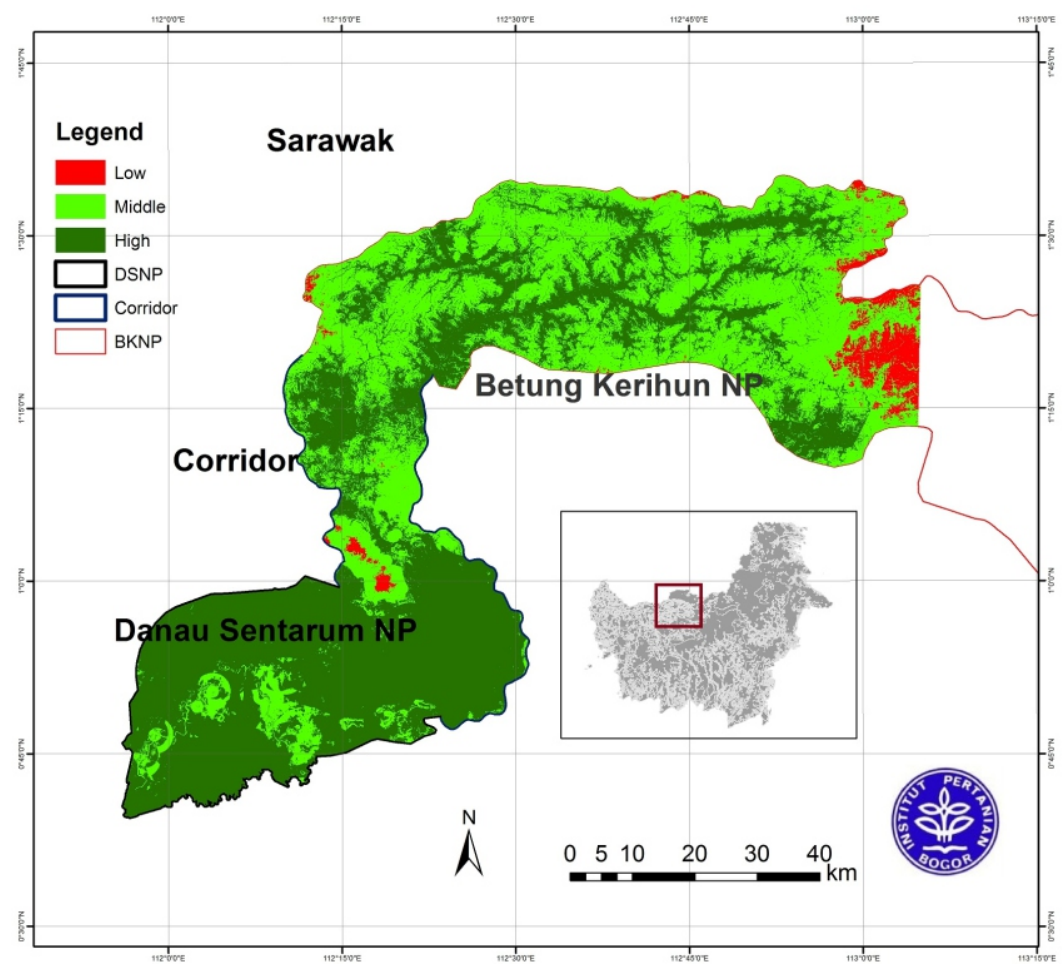

Figure 2 Habitat suitability map of orangutan in Betung Kerihun National Park (BKNP), corridor, and Danau Sentarum National Park(DSNP).

Table 11Validation result obtained from habitat suitability model of orangutan in BKNP, corridor, and DSNP

\begin{tabular}{ccc}
\hline Suitability classification & Total points & Proportion (\%) \\
\hline Low & 17 & 6.37 \\
Moderate & 176 & 65.92 \\
High & 74 & 27.76 \\
\hline & 267 & 100 \\
\hline
\end{tabular}


found in habitats that were lowland, low-slope areas, and such close to rivers or swamps. Most of research sites was considered of high and moderate suitability as habitats for orangutans, while the remaining was considered less suitable. The validation value was $93.63 \%$ representing the combination of moderate and high habitat suitability, which indicated that this area was suitable as habitat for orangutans.

\section{References}

Allouche O, Steinitz O, Rotem D, Rosenfeld A, Kadmon R. 2008. Incorporating distance constraints into species distribution models. Journal of Appllied Ecology 45(2):599-609. http://dx.doi.org/10.1111/j.1365-2664. 2007.01445.x.

Ancrenaz Metal. 2008. Pongo pygmaeus. IUCN 2013.

Bruford MW et al. 2005. Projecting genetic diversity and population viability for the fragmened orang-utan population in the Kinabatangan floodplain, Sabah, Malaysia. Endangered Species Research 12:249-261. http://dx.doi.org/10.3354/esr00295.

Bugo H. 1995. The significance of the timber industry in the economic and social development of Sarawak. In: Ecology Conservation and Management of Southeast Asian Rainforests. Primarck RB, Lovejoy TE, editors. New Haven: Yale UP. Pp221-240.

Cannon CH, Curran LM, Marshall AJ, Leighton M. 2007. Beyond mast-fruiting events: community asynchrony and individual dormancy dominate woody plant reproductive behavior across seven bornean forest types. Current Science 93(11):1558-1566.

Chefaoui RM, Hortal J, Lobo JM. 2005. Potential distribution modelling, niche characterization and conservation status assessment using GIS tools: a case study of Iberian Copris species Biology Conservation 122(2):327-338. http://dx.doi.org/10.1016/j.biocon. 2004.08.005.

Engler R, Guisan A, Rechsteiner L. 2004. An improved approach for predicting the distribution of rare and endangered species from occurrence and pseudo-absence data. Journal of Applied Ecology 41:263-274. http://dx. doi.org/10.1111/j.0021-8901.2004.008 81.x.

Gossens B et al. 2008. Taxonomy, geographic variation and population genetics of bornean and sumatran orangutans. In: Wich SA, SS Utami, TM Setia, CPP van Schaik. 2010. Orangutans: Geographic Variation in Behavioral Ecology and Conservation. Oxford: Oxford University Press.

Groves C. 2001. Primate Taxonomy. Washington DC: Smithsonian Institution Press.

Guisan A, Zimmermann NE. 2000. Predictive habitat distribution models in ecology. Ecological Modelling 135:147-186. http://dx.doi.org/10.1016/S0304-3800(00 )00354-9.
Hirzel AH et al. 2004. Ecological requirements of reintroduced species and the implications for release policy: the case of the bearded vulture. Journal of Applied Ecology 41:1103-1116. http://dx.doi.org/10.1111/j. 0021 $-8901.2004 .00980 . x$.

Ikbal W, Prasetyo LB, Risdiyanto I. 2008. Habitat suitability of javan gibbon in Gunung Salak, West Java. Jurnal Manajemen Hutan Tropika 16(1):1-8.

IUCN. 2014. IUCN Red List of Threaterned Species. Version 2013.1. http://www.iucnredlist.org [22 June 2014].

Larson AM, Dijak WD, Thompson FR, Millspaugh JJ. 2003. Landscape-level habitat suitability models for twelve wildlife species in Southern Missouri. General Technical Reports. NC-233. St. Paul, MN: U.S. Department of Agriculture, Forest Service, North Central Research Station. 51 p.

Leighton M, Leighton DR. 1983. Vertebrate responses to fruiting seasonality within a Bornean rain forest. In: Sutton SL, Whitmore TC, Chadwick AC, editors. Tropical Rain Forest: Ecology and Management. Oxford: Blackwell Scientific Publishers. Pp181-196.

Lillesand TM, RW Kiefer, Chipman JW. 2004. Remote sensing and image interpretation. $6^{\text {th }}$-ed. New York: Willey.

Locke DP et al. 2011. Comparative and demographic analysis of orang-utan genomes. Nature 469:529-533. http://dx.doi.org/10.1038/nature09 687.

Long PR, Zefania S, French-Constant RH, Szekely T. 2008. Estimating the population size of an endangered shorebird, the Madagascar plover, using a habitat suitability model. Animal Conservation 11:118-127. http://dx.doi.org/10.11 11/j.1469-1795.2008.00157.x

Majka D, Beier P, Jenness J. 2007. Corridor designer ArcGIS toolbox tutorial. http://corridordesign.org/dl/tools/CD toolbox_tutorial.pdf. [13 Oct 2013]

Marshall AJ et al. 2006. The blowgun is mightier than the chainsaw in determining population density of bornean orangutans (Pongo pygmaeus morio) in the forests of East Kalimantan. Biological Conservation 129:566-578. http://dx.doi.org/10.1016/j.biocon.2005.11.025.

Meijaard E, Rijksen HD, Kartikasari SN. 2001. Di Ambang Kepunahan!, Kondisi Orangutan Liar di Awal Abad ke21. Jakarta: The Gibbon Foundation Indonesia.

Muir CC, Galdikas BMF, Beckenbach AT. 2000. mtDNA sequence diversity of orangutans from the islands of Borneo and Sumatra. Journal Molecular Evolution 51:471-480.

Nijman V, Meijaard E. 2008. Zoogeography of primates in insular Southeast Asia: species-area relationships and the effects of taxonomy. Contributions to Zoology 


\section{7(2):117-126.}

Ottaviani D, Lasinio GJ, Boitani L. 2004. Two statistical methods to validate habitat suitability models using presence-only data. Ecological Modelling 179:417-443. http://dx.doi.org/10.1016/j.ecolmodel.2004.05.016.

Payne J. 1987. Surveying orangutan populations by counting nests from a helicopter: a pilot survey in Sabah. Primate Conservation 8:92-103.

Rahmat UM, Santosa Y, Prasetyo LB, Kartono AP. 2012. Habitat suitability modeling of javan rhino (Rhinoceros sondaicus Desmarest 1822) Ujung Kulon National Park. Jurnal Manajemen Hutan Tropika 18(2):129-137. http://dx.doi.org/10.7226/jtfm.18.2.129.

Rijksen HD, Meijaard E. 1999. Our Vanishing Relative: The status of Wild Orang-utans at The Close the Twentieth Century. Dordrecht: Kluwer Academic Publisher. http://dx.doi.org/10.1007/978-94-010-9020-9.

Singleton I, Wich S, Husson S, Stephens S, Atmoko SU, Leighton M, Rosen N, Traylor-Holzer K, Lacy R, Byers O. editors. 2004. Orangutan Population and Habitat Viability Assessment: Final Report. IUCN/SSC Conservation Breeding Specialist Group, Apple Valley, $\mathrm{MN}$.

Soemarna K, Ramono WS, Tilson R. 1995. Introduction to the orangutan population and habitat viability analysis (PHVA) workshop. In: The Neglected Ape. Nadler RD et al., editors. New York. H. Pp81-83.
Sugardjito J, van Schaick CP. 1991. Orangutans: current population status, threats, and conservation measures. In: Proceedings of the Great Apes Conference; Jakarta, Desember 18-22, 1991. Pp 142-145.

Timm NH. 2002. Applied Multivariate Analysis. New York: Springer_Verlag.

van Schaik CP, Azwar MS, Priatna D. 1995. Population estimates and habitat preferences of the orang-utan based on line transects of nests. In: Nadler RD, Galdikas BMF, Sheeran LK, Rosen N. editors. The Neglected Ape. New York and London: Plenum Press. Pp 129-147. http://dx.doi.org/10.1007/978-1-4899-1091-2_15.

Warren KS et al. 2001. Speciation and intraspecific variation of bornean orangutans, Pongo pygmaeus pygmaeus. Molecular. Biology Evolution 18:472-480. http://dx.doi. org/10.1093/oxfordjournals.molbev.a003826.

Wich SA et al. 2008. Distribution and conservation status of the orang-utan (Pongo spp) on Borneo and Sumatra: how many remain? Oryx 43(3):329-339.

Wich SA et al. 2012a. Call cultures in orang-utans? PLOS ONE 7(5):e36180. http://dx.doi.org/10.1371/journal. pone. 0036180 .

Wich SA et al. 2012b. Understanding the impacts of land-use policies on a threatened species: is there a future for the bornean orang-utan? PLOS ONE 7(11):1-10. http://dx.doi.org/10.1371/journal.pone.0049142. 